\title{
Article \\ The Use of a Genetic Algorithm for Sorting Warehouse Optimisation
}

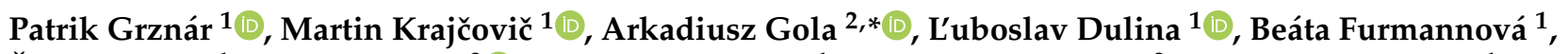 \\ Štefan Mozol ${ }^{1}$, Dariusz Plinta ${ }^{3}{ }^{\circledR}$, Natália Burganová ${ }^{1}$, Wojciech Danilczuk ${ }^{2}$ and Radovan Svitek ${ }^{1}$ \\ 1 Department of Industrial Engineering, Faculty of Mechanical Engineering, University of Žilina, \\ Univerzitná 8215/1, 01026 Žilina, Slovakia; patrik.grznar@fstroj.uniza.sk (P.G.); \\ martin.krajcovic@fstroj.uniza.sk (M.K.); luboslav.dulina@fstroj.uniza.sk (L'D.); \\ beata.furmannova@fstroj.uniza.sk (B.F.); stefan.mozol@fstroj.uniza.sk (Š.M.); \\ natalia.burganova@fstroj.uniza.sk (N.B.); radovan.svitek@fstroj.uniza.sk (R.S.) \\ 2 Department of Production Computerization and Robotization, Faculty of Mechanical Engineering, \\ Lublin University of Technology, ul. Nadbystrzycka 36, 20-618 Lublin, Poland; \\ danilczuk.wojciech@gmail.com \\ 3 Department of Production Engineering, Faculty of Mechanical Engineering and Computer Science, \\ University of Bielsko-Biala, ul. Willowa 2, 43-309 Bielsko-Biała, Poland; dplinta@ath.bielsko.pl \\ * Correspondence: a.gola@pollub.pl; Tel.: +48-81-538-45-35
}

check for updates

Citation: Grznár, P.; Krajčovič, M.; Gola, A.; Dulina, L'.; Furmannová, B.; Mozol, Š.; Plinta, D.; Burganová, N.; Danilczuk, W.; Svitek, R. The Use of a Genetic Algorithm for Sorting Warehouse Optimisation. Processes 2021, 9, 1197. https://doi.org/ $10.3390 /$ pr9071197

Academic Editors: José Barbosa and Luis Puigjaner

Received: 2 June 2021

Accepted: 7 July 2021

Published: 10 July 2021

Publisher's Note: MDPI stays neutral with regard to jurisdictional claims in published maps and institutional affiliations.

Copyright: (C) 2021 by the authors Licensee MDPI, Basel, Switzerland. This article is an open access article distributed under the terms and conditions of the Creative Commons Attribution (CC BY) license (https:// creativecommons.org/licenses/by/ $4.0 /)$.

\begin{abstract}
In the last decade, simulation software as a tool for managing and controlling business processes has received a lot of attention. Many of the new software features allow businesses to achieve better quality results using optimisation, such as genetic algorithms. This article describes the use of modelling and simulation in shipment and sorting processes that are optimised by a genetic algorithm's involvement. The designed algorithm and simulation model focuses on optimising the duration of shipment processing times and numbers of workers. The commercially available software Tecnomatix Plant Simulation, paired with a genetic algorithm, was used for optimisation, decreasing time durations, and thus selecting the most suitable solution for defined inputs. This method has produced better results in comparison to the classical heuristic methods and, furthermore, is not as time consuming. This article, at its core, describes the algorithm used to determine the optimal number of workers in sorting warehouses with the results of its application. The final part of this article contains an evaluation of this proposal compared to the original methods, and highlights what benefits result from such changes. The major purpose of this research is to determine the number of workers needed to speed up the departure of shipments and optimise the workload of workers.
\end{abstract}

Keywords: computer simulation; genetic algorithm; shipment; sorting; optimisation; logistic

\section{Introduction}

The shipping industry is still figuring out how to manage its processes in a costeffective and efficient manner. As a result, several delivery companies seek out cutting-edge solutions to improve customer experience and revenues [1,2]. Whether it is a company with a large or small volume of shipments, it is always necessary to adhere to specific transport standards of, and solutions to, the sorting process. A delivery company often stands as a link between a product's manufacturer and customers [3]. Such a company will ensure customer satisfaction mainly by fast delivery, suitable packaging of the consignment and, last but not least, the lowest price. This is why it is crucial to continually improve said company's logistics processes $[4,5]$. In a delivery company, every process is closely linked; it must therefore respond flexibly to every change and error in the process [6]. This means that the delay of one element of a shipment and sorting processes will be reflected in the next process $[7,8]$.

Today, modelling and simulations are commonly used for all production or logistics companies $[9,10]$. Due to the sensitivity of delivery processes, finding the optimal solution 
with the highest possible quality is necessary [11,12]. Simulation can be especially useful in cases involving a complex system with dynamic inputs and conditions $[13,14]$. It can be used not only for the determination of a future object's state but also to determine the optimal path to achieve this state $[15,16]$. Genetic algorithms (GA) are commonly used to generate high-quality solutions, as well as to optimise and search for problems by relying on biologically inspired operators such as mutations, crossover, and selection $[17,18]$. The advantages of such algorithms include, for example, the ability to implement GAs as a "universal optimiser" that can be used to optimise any type of problem belonging to different areas $[19,20]$. Genetic algorithms in the field of logistics are an area of interest for many researchers. Figure 1 presents the number of publications on genetic algorithm issues in the context of logistics (based on data from the Scopus database).

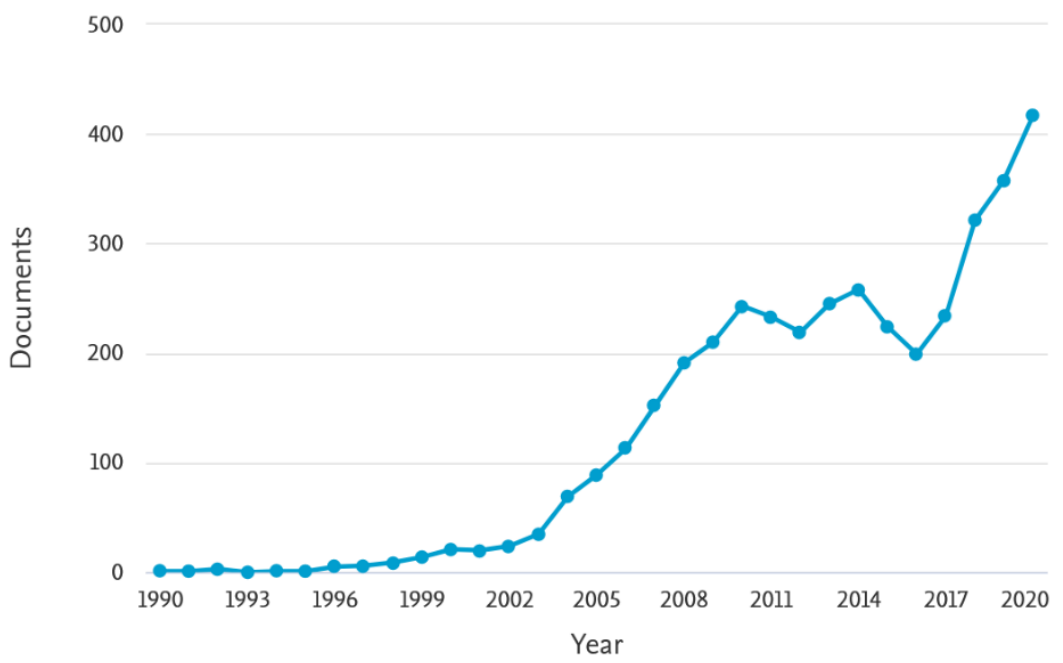

Figure 1. Number of publications on genetic algorithms and logistics.

As will be demonstrated further, this technique can solve practical problems that occur in logistics companies. This technique has tremendous efficiency and performs well in creating complex adaptations. A GA can find elegant, multifactorial solutions to problems in hidden ways, problems that a researcher may be unaware of and that are unlikely to be discovered by traditional engineering approaches [21,22].

Based on [23], the selection of model structure and model parameter identification are two main problems in system identification. There is currently a growing number of uses of genetic algorithms to solve various tasks because of its advantages, such as wide adaptability, stable calculation, high identification accuracy, and simultaneous determination of the model structure and parameters. A linear system, system order, time lag, and parameters can be constituted into a chromosome. The value of fitness function includes the modelling error thanks to the system identification problem becoming an optimal problem that a GA can solve.

There are many areas where genetic algorithms find application in optimisation, such as artificial intelligence [24], robotics [25], services [26], automatic control [27], manufacturing [28], and warehouses. Genetic algorithms are used in warehouses in various ways, such as solving problems related to the utilisation of material items' locations, determining the appropriate inventory size of individual material items, and determining the speed and schedule of the replenishment of material items [29]. By testing the genetic algorithm in terms of replenishment of stocks, it was found that as little time as possible was devoted to this task [30,31]. Optimisation to find the optimal placement solution can be found in [32]. Optimisation of the AGV route in warehouses was carried out in $[33,34]$. 


\section{Problem Definition}

For the solution and subsequent optimisation, the problem of determining the number of personnel in a consignment sorting warehouse is chosen. Siemens' Tecnomatix Plant Simulation 15.2 software is used to implement the solution. The quantity of sorting volume in a warehouse is not constant and tends to fluctuate depending on the volume of shipments on any given day. As a result, a warehouse is used by both permanent employees and largely part-time workers who are ordered in a fixed number every day. It is never certain how many temporary workers will be required on any one day. $4 \mathrm{~h}$ before sorting begins, the quantity of consignments received is known. Every day, it is required to ensure that sorted consignments are loaded onto transport trailers as soon as possible in both directions. Using a routine estimate to optimise the amount of personnel for a complex sorting facility on a daily basis is a difficult assignment. It is assumed that a large number of people are completing jobs at maximum capacity; therefore, leaving trucks with sorted items is the best option. The goal of this research is to develop a system for determining the number of workers and inputs for a given day, while allowing each truck to depart from the sorted consignments first. According to the proposed algorithm, the results are calculated for a specified volume of consignments. On the basis of this optimisation, a simulation model of a shipment sorting warehouse is used, with genetic algorithms being used to reduce the number of experiments.

The article's main purpose is to highlight the advantages that optimisation in the form of simulation using genetic algorithms can offer to the stated case study of applied research in a sorting depot. The fundamental goal of optimisation is to obtain the most feasible time structure for sorting processes while maximising the utilisation of labour resources. The result is a process for determining the number of workers for the sorting depot for a certain number of shipments at various time intervals, using genetic algorithms to construct simulation experiments.

\section{Materials and Methods}

\subsection{Genetic Algorithms}

A genetic algorithm (GA) was employed to determine the best solution for various processes in the simulation model, as previously described. One of the most basic stochastic optimisation techniques with considerable evolutionary characteristics is the genetic algorithm. To solve a problem, it represents an intelligent use of random selection from a defined search space. A GA solves multiple tasks concurrently, allowing for a global search for the best solution. It is currently the most extensively used evolutionary optimisation algorithm, with several theoretical and practical applications. The genetic algorithm considers five steps [28].

\subsubsection{First Phase: Initial Population}

The procedure starts with a group of people known as a population. Each person is the answer to the problem one is trying to solve. Genes are a set of factors that characterise an individual. A chromosome is made up of genes that are connected together.

A set of an individual's genes is represented by a string in the form of an alphabet in a genetic algorithm. Binary values are commonly utilised. On a chromosome, we claim we encode genes [21].

\subsubsection{Second Phase: Fitness Function}

The fitness function determines an individual's level of fitness. It assigns a fitness score to each individual. The likelihood of an individual being chosen for reproduction is determined by their fitness score [35].

\subsubsection{Third Phase: Selection}

The goal of the selection phase is to choose the most capable individuals and allow them to pass on their genes to future generations. Two pairs of people (parents) are chosen 
depending on their fitness levels. Physically fit individuals have a better likelihood of deciding to reproduce [35].

\subsubsection{Crossover}

Crossover, the most essential phase of the genetic algorithm is shown in Figure 2. A crossing point is chosen at random from the genes for each pair of parents to be mated. Progeny are created by exchanging genes between parents until a cut-off point is reached. The population grows by adding new progeny [35].

\begin{tabular}{|ll|l|l|l|} 
Parent 1 & KRTAS & JOSRWA & RI & MUZDWQST \\
Parent 2 & NRQIE & PGECVI & BC & LXWTMIPQ \\
\hline & \multicolumn{4}{|c|}{} \\
Children 1 & KRTAS & PGECVI & RI & LXWTMIPQ \\
Children 2 & NRQIE & JOSRWA & BC & MUZDWQST \\
\hline
\end{tabular}

Figure 2. Crossover.

\subsubsection{Mutation}

Some of their genes may be altered with a low random frequency in newly generated offspring (Figure 3). Some bits in a bit-string can be reversed as a result of this mutation [22].

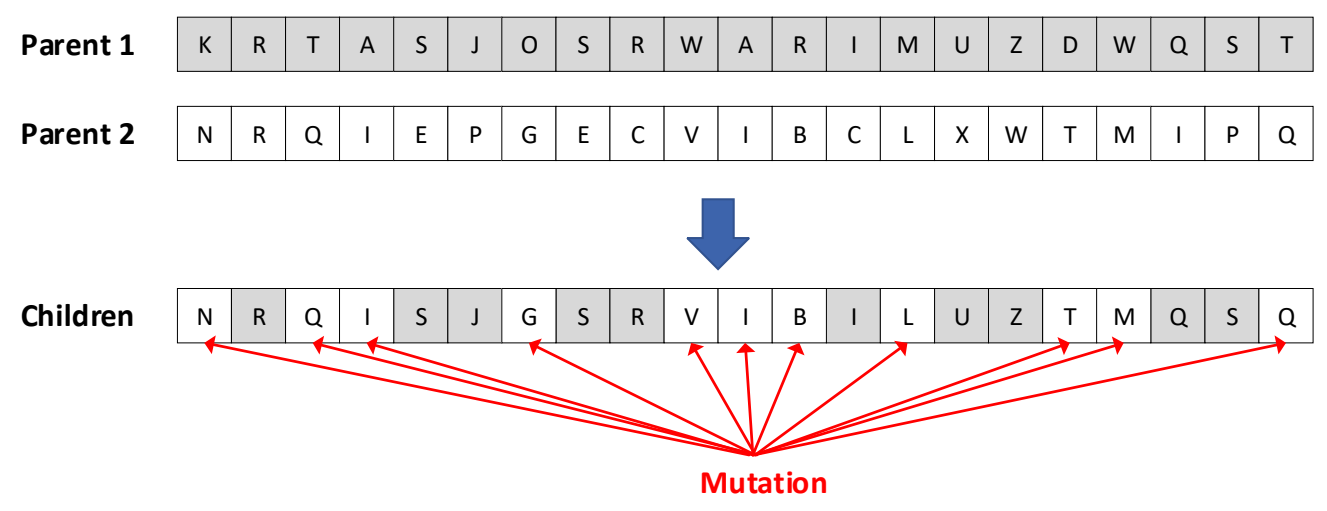

Figure 3. Mutation.

\subsubsection{Tecnomatix Plant Simulation and Genetic Algorithms}

Tecnomatix Plant Simulation is a Siemens PLM Software computer tool for the modelling, simulation, analysis, visualisation, and optimisation of manufacturing systems and processes, as well as material flow and logistical operations. It also enables the virtual device model to be coupled with real-world plant management in order to imitate real-world production. Control, automation, material transport, and the full technical operation may all be tested and optimised using this integrated simulation approach. The fundamentals of genetic algorithms in Tecnomatix software are the same as in biology. The most successful solutions are chosen from a pool of potential solutions and used to develop new ones. Then, in future generations, better solutions are developed. The so-called fitness value, which the simulation model provides, determines whether the proposed solution has an advantage in selection and determines whether it is then employed to create a new solution. The simulation model shows one how long each proposed sequence takes to process [36].

The key benefits of genetic algorithms are that they are job-agnostic and produce satisfactory results. As a result, genetic algorithms are well suited to assisting numerous simulation-based optimisation tasks. Genetic algorithms can handle a variety of problems 
without requiring a lot of time to construct and adjust simulation models. To solve the optimisation challenge, genetic algorithms employ an iterative approach. The simulation model determines the acceptability of offered solutions based on stated fitness parameters. The optimal solution is determined when the optimisation cycles are completed and it is ready to be used for future modelling. The objects displayed in Figure 4 are made possible by further genetic algorithms, see Figure 4.

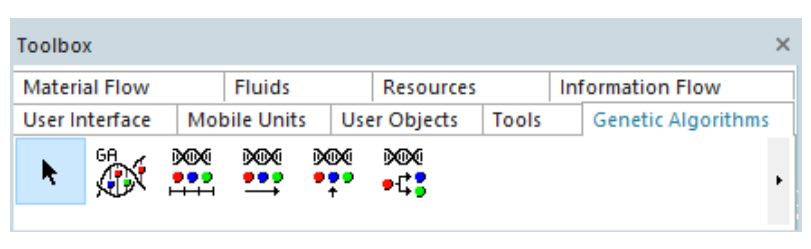

Figure 4. Objects which provide genetic algorithms in software Tecnomatix Plant Simulation.

2.2. Design of Algorithm for Determining the Number of Workers in the Sorting Warehouse Using Genetic Algorithms

The case study is conducted using the algorithm for determining the number of employees in the sorting warehouse (Figure 5), in which the target function is the departure time of the final truck with sorted consignments and the number of employees. Start 1 and Start 2 are the two beginnings of the algorithm. Start 1 is the first step in the project and its purpose is to generate a viable and verified model using Tecnomatix Plant Simulation's GAWizard function (gray). Start 2 is used by the user on a daily basis to calculate the number of workers required for a given day so that the truck can leave as soon as feasible, and the designated workers' workload is as high as possible (white). The task of the colour genetic algorithm, which is marked in blue, is to arrange experiments and conduct simulation runs.

\subsection{Design of Simulation Model}

As already mentioned, the software Tecnomatix Plant Simulation 15.2 is used to implement the simulation model. It enables the insertion of items and their modelling so that the modelled objects are comparable in size and shape to the real ones, allowing for extremely accurate distance and time estimates. It also has a worker function, which allows researchers to replicate the worker's behaviour and actions (sorting, carrying, unloading, loading). The main part of the simulation model is the conveyor system, which distributes consignments to the sorters and, subsequently, to the conveyors and the transport trailers (see Figure 6).

There are three critical input locations for shipments for sorting in the model. Input 1 reflects courier-imported shipments. Input 2 is the location where letter items are entered. Input 3 is the input of shipments from a single shipper, but in bigger quantities. Consignments imported by trucks for sorting from different locations are represented by inputs 4, 5 and 6. Without simulation, it is decided which worker performs a specific activity. Their present estimate is 21 ; however, their utilisation is extremely low due to a lack of work coordination on activities. When modelling inputs 4,5 , and 6 , it is assumed that no more than three trucks can unload at the same time, see Figure 7 . Point outputs 7 to 16 are workers who were assigned to remove the consignment off the conveyor belt, inspect it, and place it in the loaded truck.

After validation and verification, a simulation model was developed based on the present state, which included all necessary objects and exhibited appropriate accuracy. The model is displayed in 2D view on Figure $8 \mathrm{a}$ and in $3 \mathrm{D}$ view on Figure $8 \mathrm{~b}$. The time in which the simulation can be run is one of the model's primary constraints. The moment when the quantity of bales for each direction is known, as well as the estimated arrival time of the sorting trucks, which occurs $4 \mathrm{~h}$ prior to the beginning of sorting process. We can rely on past data up to this point, but they do not produce reliable findings. 


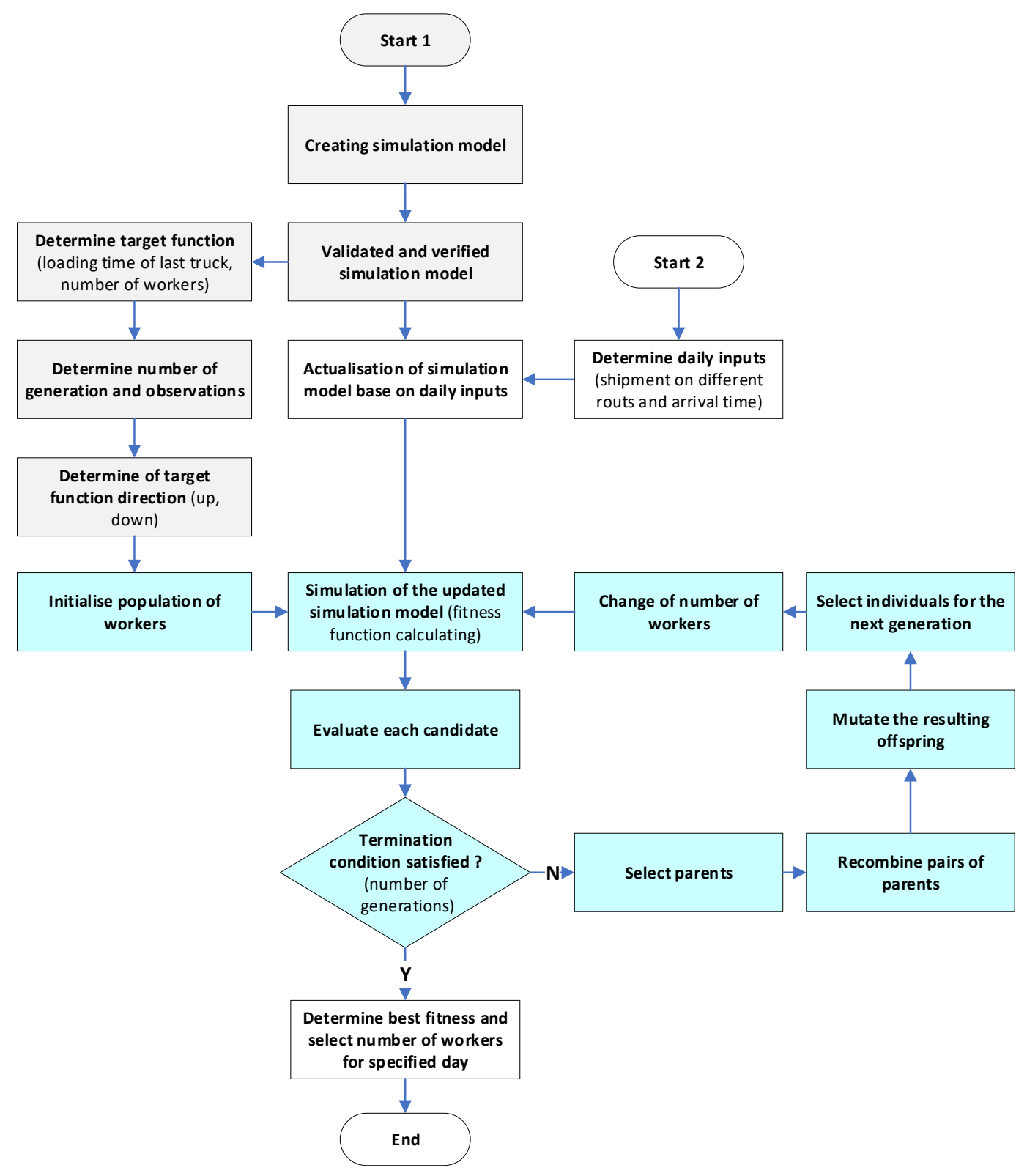

Figure 5. Genetic algorithms are used in a simulation to determine the number of workers in a sorting warehouse.

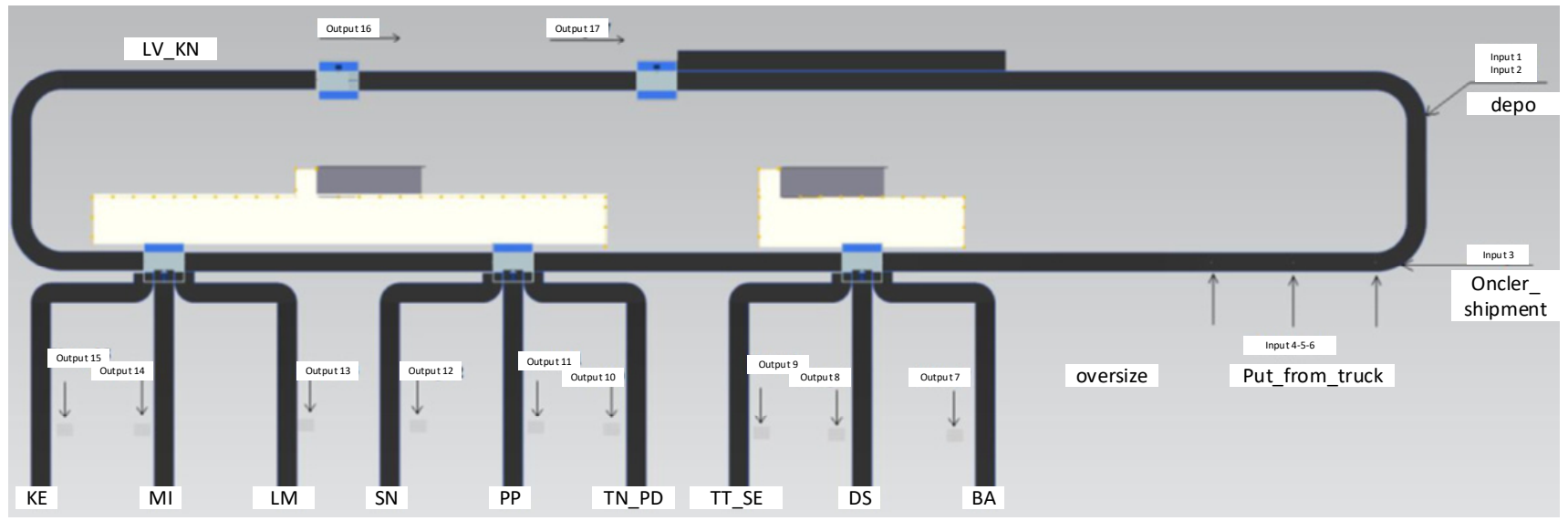

Figure 6. Conveyor system of sorting in the warehouse and workplaces. 


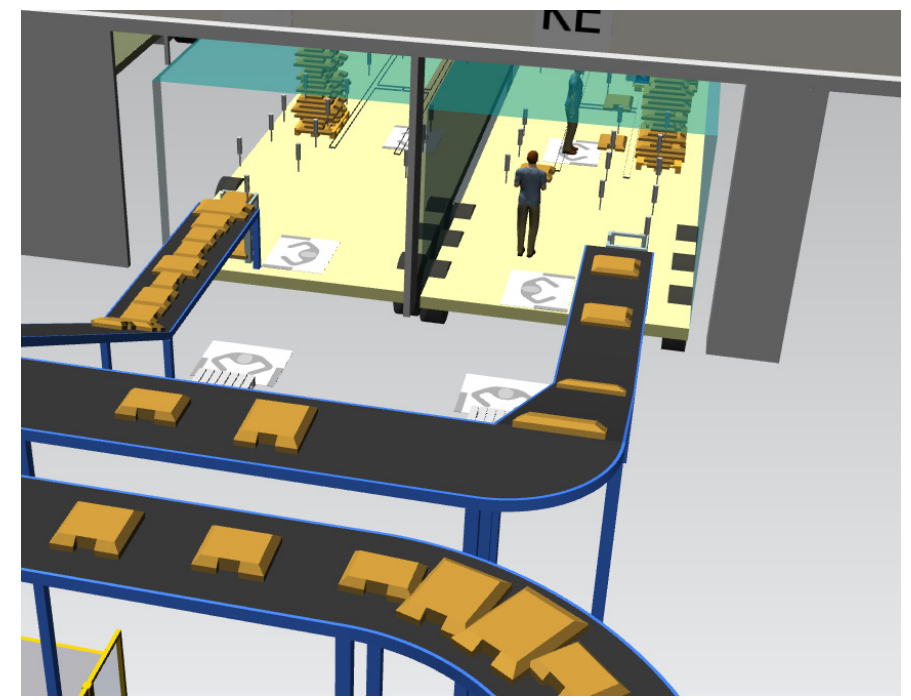

Figure 7. Loading of shipments into the truck after sorting.

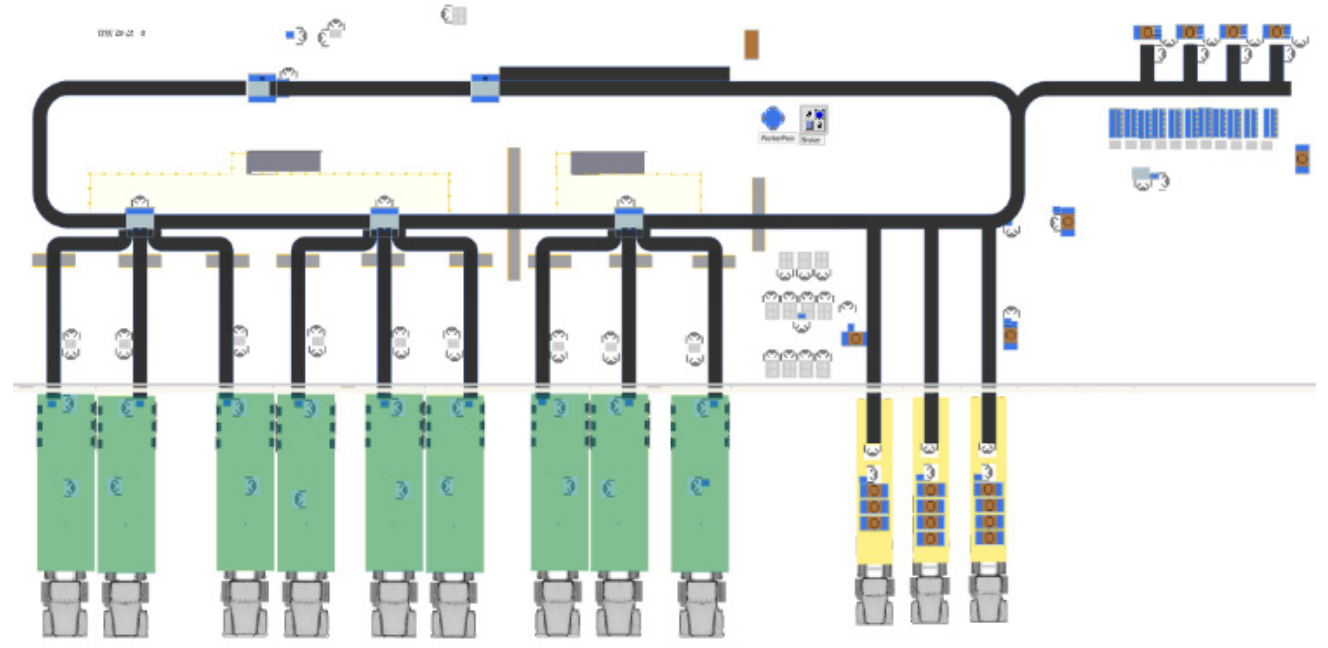

(a)

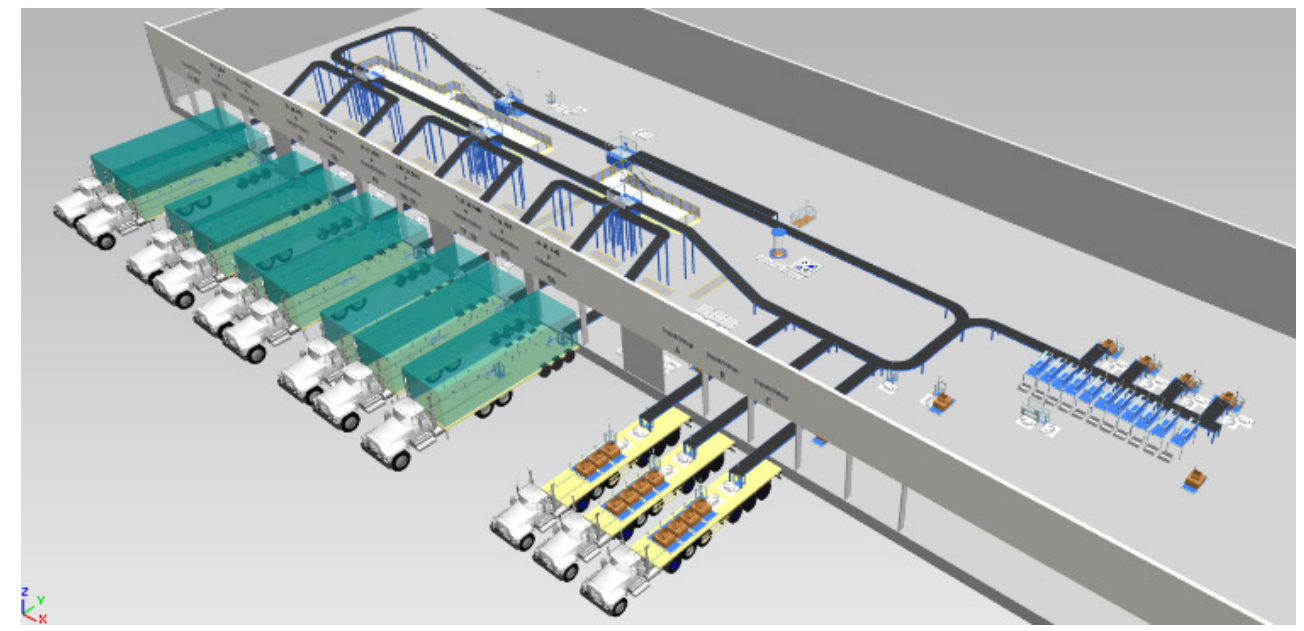

(b)

Figure 8. Actual simulation model: (a) 2D view; (b) 3D view. 
In total, 8330 consignments were used as an input to compare the current condition in terms of the number of workers and truck departure times. The daily cost for one permanent employee is EUR 9 and, for part-time employees, it is EUR 6. The cost of failing to arrive at the next processing location on time is EUR 6 each minute. The departure of the last sorted vehicle at $5 \mathrm{~h} 40 \mathrm{~min} 00 \mathrm{~s}$ is the period that should not be exceeded in order to avoid these fees. Without the simulation model, the number of employees was calculated using a conventional estimate based on the table, which shows that there are seven employees for every 1500 shipments. As a result, 42 staff are ready to participate in the simulation. The end of the simulation with this number is $5 \mathrm{~h} 28 \mathrm{~min} 53.42 \mathrm{~s}$ and the occupancy rate is $20 \%$, according to the results. The GAWizard function in the software allows one to define the target function, which is the value that should be optimised and weighted. The loading time of the last truck, i.e., the time when the simulation is finished, and the number of personnel were our two functions. At each simulation run, we aimed for the smallest possible number of personnel and the soonest possible truck departure of the last truck. A fitness function was established. When optimising the last track's departure time, the number of workers had a weight of 1 while optimising the last track's departure time had a weight of 0.5 .

In order to optimise the number of employees, integer variables representing employees were constructed. Their number corresponded to the zone in which they engaged in a certain set of activities. The zones that were optimised, as well as their activities, are depicted in Table 1.

Table 1. Range of activities in different zones.

\begin{tabular}{cccc}
\hline ZoneA & ZoneB & ZoneC & ZoneD \\
\hline Carry_SN & Carry_BA & carry_dep_I & Sorting_oversize \\
Carry_TN_PDCarry_PP & Carry_DS & carry_depo_II & Carry_input_from_track_A \\
Carry_LM & Carry_TT_SE & carry_depo_III & Carry_input_from_track_C \\
Carry_MI & Delivery_oversize & carry_depo_IV & Carry_input_from_track_B \\
Carry_KE & Carry_TN_PD & carry_oncler_shipment & \\
Carry_LV_KN & Carry_PP & Carry_input_from_track_A & Carry_BA \\
& & Carry_DS & \\
& &
\end{tabular}

The genetic algorithm can identify the best fitness function, i.e., the combination of factors that result in the best fitness by combining the number of variables. In the models, there are variables that change and variables that do not change. Figure 9 depicts constant variables on the right and altered variables on the left.

\begin{tabular}{ll|}
\hline Zone A = 12 & SortingMI_KE_LM= 1 \\
\hline ZoneB = 5 & SortingTN_PD_PP_SN = 1 \\
\hline \hline ZoneC = 12 & Sorting_BA_DS_TT_SE = 1 \\
\hline InputZone = 13 & ZonePostal= 1 \\
\hline
\end{tabular}

Figure 9. Current setting of the number of employees in the proposed variables.

These variables are set in the GAWizard as "problem definition", where we specify the lower (1) and upper (10) number of workers and the increment step (1) for each zone. The increment step defines how many experiment simulations we attain. The number of observations is also defined, namely 3 , as is the number of generations (20).

\section{Results}

Using genetic algorithms, optimisation was started based on the input data. The value is checked after each simulation, and another experiment was constructed, reducing the 
number of experiments. With a total of 960 simulation runs completed for 320 experiments with three observations, each generation improved. Without the use of genetic algorithms, 10,000 experiments with three observations would have to be performed. Figure 10 shows the development of fitness values for the best, average, and worst solutions in each generation. Graphs in Figure 11 show all fitness values for each generation.

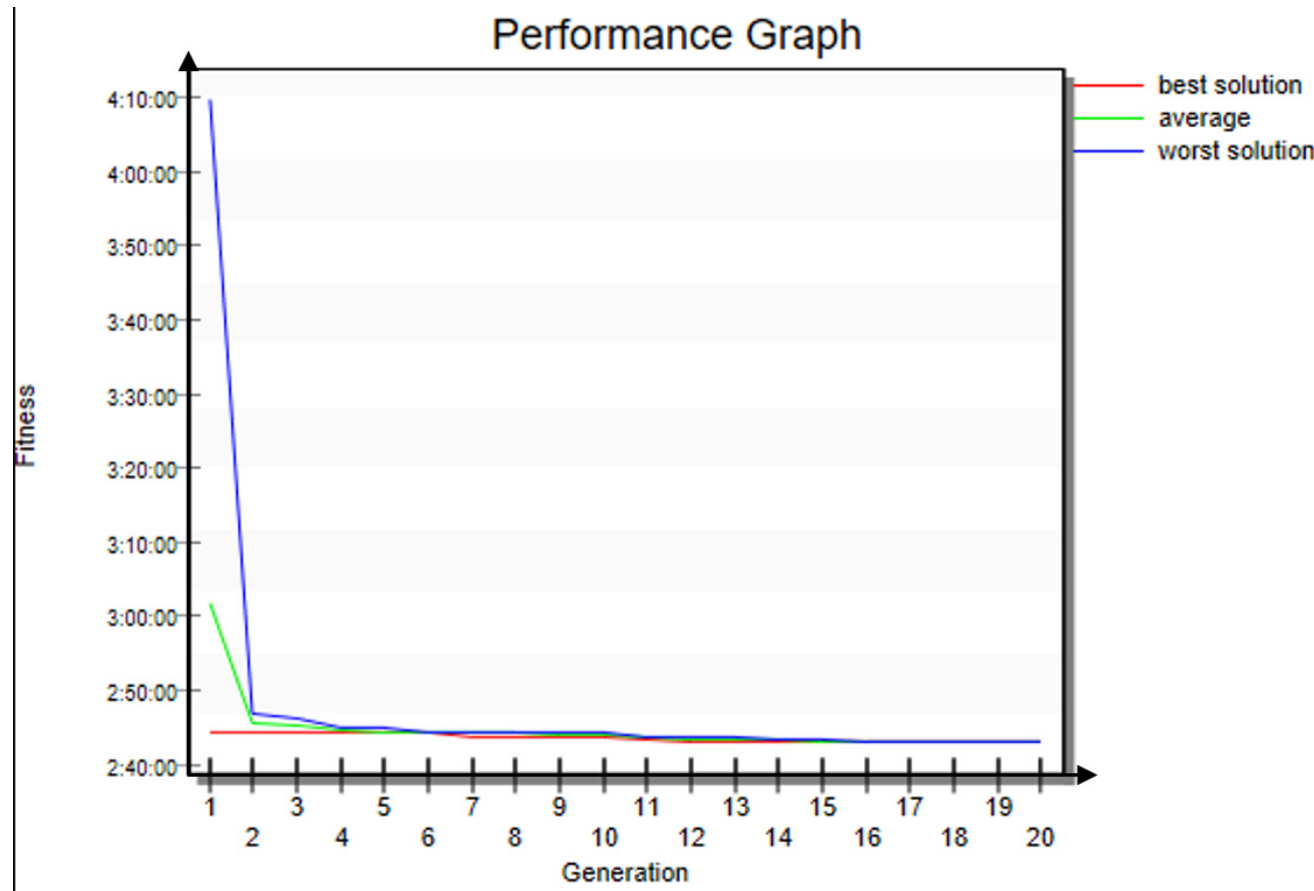

Figure 10. Graph showing the development of fitness values for the best, average, and worst solution in each generation.

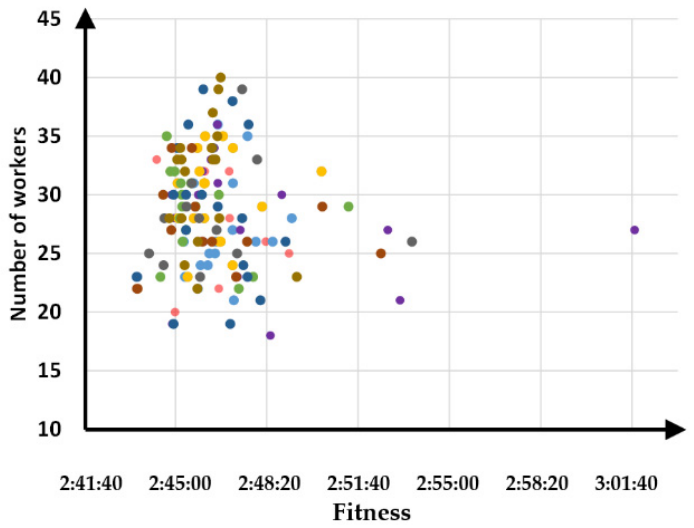

(a)

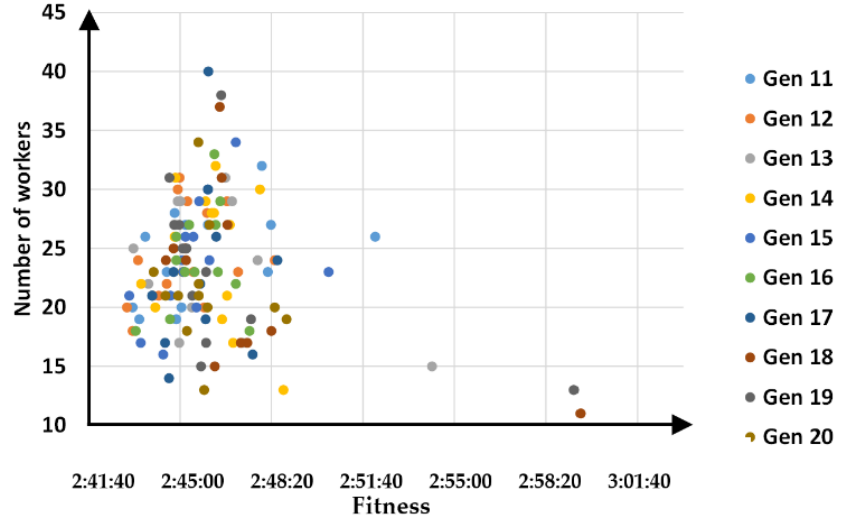

(b)

Figure 11. Graph showing all fitness values for each generation: (a) for generation 1 to 10; (b) for generation 11 to 20.

For the 16 core CPU, the simulation and planning of the tests using genetic algorithms took a total of $0 \mathrm{~h} 21 \mathrm{~min} 20 \mathrm{~s}$. If all 10,000 experiments are carried out, the simulation takes $11 \mathrm{~h} 06 \mathrm{~min} 40 \mathrm{~s}$, which is insufficient if temporary staff must be reserved promptly. When compared to the standard simulation $10 \mathrm{~h} 45 \mathrm{~min} 20 \mathrm{~s}$, genetic algorithms save time (see Figure 12). In terms of costs, the company employs four regular employees and a few day-to-day recruits. Costs for staff, temporary workers, and delaying the departure of the truck with sorted consignments make up the resulting costs. Costs are used as a benchmark. 


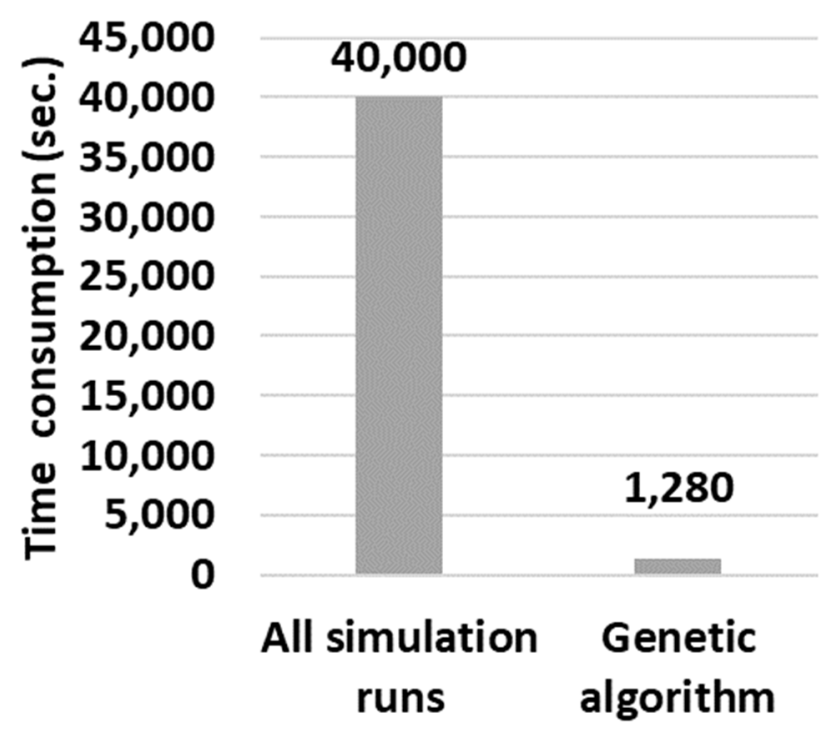

(a)

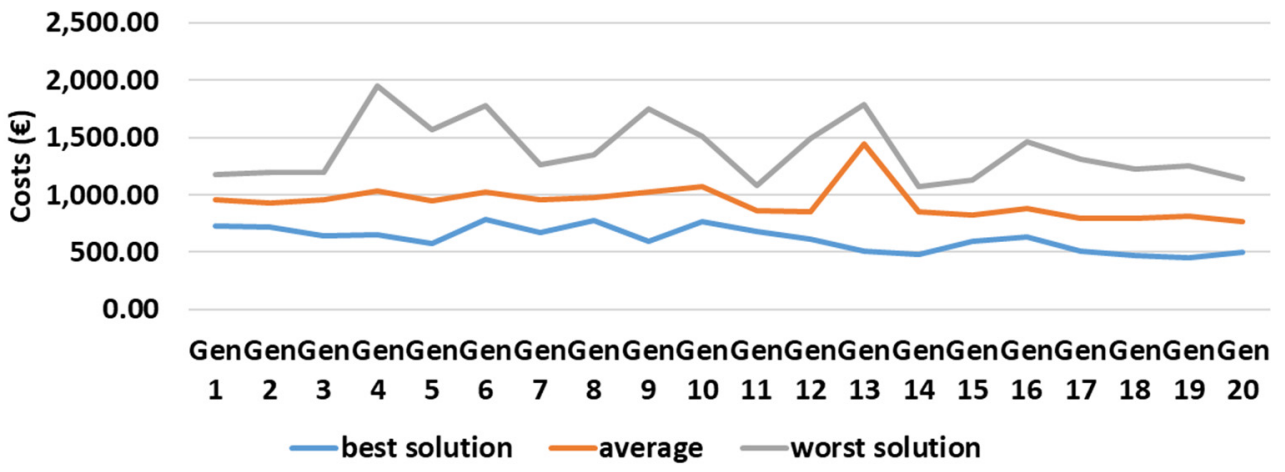

(b)

Figure 12. (a) A time-consuming simulation run without genetic algorithms and a simulation run with genetic algorithms; (b) the cost of the best, average, and worst solutions for generations.

After implementing the experiments, a table of the best solutions was generated, with the corresponding values of fitness shown in Table 2.

Table 2. Best result in optimisation using genetic algorithms for three observations.

\begin{tabular}{cccc}
\hline Fitness & $\begin{array}{c}\text { End of the } \\
\text { Simulation }\end{array}$ & $\begin{array}{c}\text { Number of } \\
\text { Employees }\end{array}$ & Costs (EUR) \\
\hline $2: 43: 23.5794$ & $5: 26: 07.1587$ & 20 & 451.11 \\
$2: 42: 49.5336$ & $5: 24: 59.0671$ & 20 & 451.00 \\
2:43:01.1835 & $5: 25: 22.3670$ & 20 & 451.03 \\
\hline
\end{tabular}

The specified number of workers for each zone is shown in Table 3.

Table 3. Specified number of workers for different zones.

\begin{tabular}{cccc}
\hline ZoneA & ZoneB & ZoneC & ZoneD \\
\hline 10 & 2 & 1 & 3 \\
\hline
\end{tabular}

With the stated distribution, the workload is reduced by $25 \%$. Utilisation cannot be used as a performance metric because greater values can only be achieved by reducing 
the number of personnel or changing the arrival time of trucks for sorting, both of which are impossible.

\section{Conclusions}

Current computing technologies allow us to realise what formerly could only be decided by a rough estimate, resulting in a waste of resources due to inaccurate estimates. Computing technologies and simulation software allow for precise estimation of the action's outcome without interfering with a real system. Due to the large number of dynamic activities, such as sorting goods in a logistics warehouse, determining the number of personnel needed to maximise capacity is difficult. As soon as possible, the sorting trucks should depart, and the number of workers should be kept to a minimum. This article contains an algorithm to determine the optimal number of workers in a sorting warehouse with the results of its application. The programme Tecnomatix Plant Simulation and the function of genetic algorithms were used in the implemented example to predict the number of employees. We were able to cut the number of employees by $52.38 \%$ while preserving the trucks' departure time thanks to this algorithm's assistance. Costs were reduced from EUR 727.70 to EUR 451.00. It was feasible to avoid the waste of labour resources by using simulation, and the time required to determine the ideal solution was considerably decreased by employing genetic experiments, which required just 320 experiments instead of 10,000 to find a solution.

The study, according to the authors, demonstrates the efficacy of genetic algorithms and the legality of their application in logistics organisations. GAs may not only be a subject for academic debate, but they can also help solve real-world challenges in industry. The spread of computer technology and simulation tools lays the groundwork for an increasing number of businesses to adopt genetic algorithms.

Author Contributions: Conceptualization, P.G. and A.G.; methodology, M.K.; software, Š.M.; validation, N.B. and R.S.; formal analysis, W.D.; investigation, L.D.; resources, P.G.; data curation, Š.M.; writing—original draft preparation, P.G.; writing—review and editing, A.G.; visualization, B.F.; supervision, D.P. All authors have read and agreed to the published version of the manuscript.

Funding: Scientific Grant Agency of the Ministry of Education, Science, Research and Sport of the Slovak Republic VEGA grant number [No 1/0225/21].

Institutional Review Board Statement: Not applicable.

Informed Consent Statement: Not applicable.

Data Availability Statement: The data presented in this study are available on request from the corresponding author. The full text of data is not publicly available due to company privacy.

Conflicts of Interest: The authors declare no conflict of interest.

\section{References}

1. Milan, G.; Hodon, R.; Binasova, V.; Dulina, L.; Gaso, M. Design of simulation-emulation logistics system. MM Sci. J. 2018, 2018, 2498-2502. [CrossRef]

2. Plinta, D.; Dulina, L. Ergonomics analysis in the context of a digital factory. In Proceedings of the 38th International Conference on Information Systems Architecture and Technology, ISAT 2017, Szklarska Poreba, Poland, 17-19 September 2017; Volume 657, pp. 304-313. [CrossRef]

3. Gola, A. Design and Management of Manufacturing Systems. Appl. Sci. 2021, 11, 2216. [CrossRef]

4. Yadavalli, V.S.; Balcou, C. A supply chain management model to optimise the sorting capability of a 'third party logistics' distribution centre. S. Afr. J. Bus. Manag. 2017, 48, 77-84. [CrossRef]

5. Jankowska, D.; Mikušová, M.; Wacowska-Ślęzak, J. Mobility Issues in Selected Regions of Poland and Slovakia-Outcomes of International Project SOL (Save Our Lives) Survey. Period. Polytech. Transp. Eng. 2014, 43. [CrossRef]

6. Danilczuk, W.; Gola, A. Computer aided material demand planning using ERP systems and Business Intelligence Technology. Appl. Comput. Sci. 2020, 16, 42-55. [CrossRef]

7. Mikusova, M.; Abdunazarov, J.; Zukowska, J. Modelling of the Movement of Designed Vehicles on Parking Space for Designing Parking. In Development of Transport by Telematics; Mikulski, J., Ed.; Springer International Publishing Ag: Cham, Switzerland, 2019; Volume 1049, pp. 188-201. [CrossRef] 
8. Kliment, M.; Trebuna, P.; Pekarcikova, M.; Straka, M.; Trojan, J.; Duda, R. Production Efficiency Evaluation and Products' Quality Improvement Using Simulation. Int. J. Simul. Model. 2020, 19, 470-481. [CrossRef]

9. Gola, A.; Pastuszak, Z.; Relich, M.; Sobaszek, Ł.; Szwarc, E. Scalability analysis of selected structures of a reconfigurable manufacturing system taking into account a reduction in machine tools reliability. Ekspolatacja Niezawodn. Maint. Reliab. 2021, 23, 242-252. [CrossRef]

10. Górnicka, D.; Kochańska, J.; Burduk, A. Production Resources Utilization Improvement with the Use of Simulation Modelling. Adv. Intell. Syst. Comput. 2019, 1051, 41-50. [CrossRef]

11. Ristvej, J.; Ondrejka, R.; Simak, L.; Lovecek, T.; Holla, K.; Lacinak, M.; Surinova, L.; Janosikova, M. Simulation Technologies in Risk Prevention within Crisis Management. In Proceedings of the Modelling and Simulation 2016-European Simulation and Modelling Conference, Las Palmas, Spain, 26-28 October 2016; pp. 327-330.

12. Zagorecki, A.; Ristvej, J.; Comfort, L.K.; Lovecek, T. Executive dashboard systems for emergency management. Komunikacie 2012, 14, 82-89.

13. Bubeník, P.; Horák, F. Proactive Approach to Manufacturing Planning. Qual. Innov. Prosper. 2014, 18, 23-32. [CrossRef]

14. Edl, M.; Votava, V.; Ulrych, Z.; Korecký, M.; Trkovský, V. Analysis and Optimisation of Complex Small-Lot Production in New Manufacturing Facilities Based on Discrete Simulation. In Proceedings of the 20th European Modeling \& Simulation Symposium, Amantea, Italy, 17-19 September 2008; pp. 198-203.

15. Sobrino, D.R.D.; Košt'ál, P.; Cagáňová, D.; Čambál, M. On the Possibilities of Intelligence Implementation in Manufacturing: The Role of Simulation. Appl. Mech. Mater. 2013, 309, 96-104. [CrossRef]

16. Saha, S.; Vasegaard, A.; Nielsen, I.; Hapka, A.; Budzisz, H. UAVs Path Planning under a Bi-Objective Optimization Framework for Smart Cities. Electronics 2021, 10, 1193. [CrossRef]

17. Bučková, M.; Skokan, R.; Fusko, M.; Hodoň, R. Designing of logistics systems with using of computer simulation and emulation. Transp. Res. Procedia 2019, 40, 978-985. [CrossRef]

18. Pekarcikova, M.; Trebuna, P.; Kliment, M.; Rosocha, L. Material Flow Optimization through E-Kanban System Simulation. Int. J. Simul. Model. 2020, 19, 243-254. [CrossRef]

19. Močilan, M.; Žmindák, M.; Pecháč, P.; Weis, P. CFD Simulation of Hydraulic Tank. Procedia Eng. 2017, 192, 609-614. [CrossRef]

20. Sobaszek, Ł.; Gola, A.; Kozłowski, E. Application of survival function in robust scheduling of production jobs. In Proceedings of the 2017 Federated Conference on Computer Science and Information Systems (FEDCSIS), Prague, Czech Republic, 4-7 September 2017; Ganzha, M., Maciaszek, M., Paprzycki, M., Eds.; IEEE: New York, NY, USA, 2017; pp. 575-578. [CrossRef]

21. Dulina, L.; Bartanusova, M. CAVE Design Using in Digital Factory. Procedia Eng. 2015, 100, 291-298. [CrossRef]

22. Durica, L.; Micieta, B.; Bubeník, P.; Binasova, V. Manufacturing multi-agent system with bio-inspired techniques: Codesa-prime. MM Sci. J. 2015, 2015, 829-837. [CrossRef]

23. Tao, J.; Zhang, R.; Zhu, Y. DNA Computing Based Genetic Algorithm: Applications in Industrial Process Modeling and Control; Springer: Singapore, 2020. [CrossRef]

24. Tabassum, M.; Mathew, K. A genetic algorithm analysis towards optimization solutions. Int. J. Digit. Inf. Wirel. Commun. 2014, 4, 124-142. [CrossRef]

25. Ayala, H.V.H.; Coelho, L.D.S. Tuning of PID controller based on a multiobjective genetic algorithm applied to a robotic manipulator. Expert Syst. Appl. 2012, 39, 8968-8974. [CrossRef]

26. Lopez, J. Optimisation with Matlab Using the Genetic Algorithm. Multiobjective Optimisation; Amazon Digital Services LLC-Kdp Print US: Seattle, WA, USA, 2019.

27. Zou, T.; Wu, S.; Zhang, R. Improved state space model predictive fault-tolerant control for injection molding batch processes with partial actuator faults using GA optimization. ISA Trans. 2018, 73, 147-153. [CrossRef]

28. Krajčovič, M.; Hančinský, V.; Dulina, L.; Grznár, P.; Gašo, M.; Vaculík, J. Parameter Setting for a Genetic Algorithm Layout Planner as a Toll of Sustainable Manufacturing. Sustainability 2019, 11, 2083. [CrossRef]

29. Zhang, C.; Yang, J. Genetic Algorithm for Materialized View Selection in Data Warehouse Environments. In Data Warehousing and Knowledge Discovery; Mohania, M., Tjoa, A.M., Eds.; Lecture Notes in Computer Science; Springer: Berlin/Heidelberg, Germany, 1999; pp. 116-125. [CrossRef]

30. Yao, M.; Chu, W. A genetic algorithm for determining optimal replenishment cycles to minimize maximum warehouse space requirements. Omega 2008, 36, 619-631. [CrossRef]

31. Yang, W.; Chan, F.T.; Kumar, V. Optimizing replenishment polices using Genetic Algorithm for single-warehouse multi-retailer system. Expert Syst. Appl. 2012, 39, 3081-3086. [CrossRef]

32. Qin, G.; Li, J.; Jiang, N.; Li, Q.; Wang, L. Warehouse Optimization Model Based on Genetic Algorithm. Math. Probl. Eng. 2013, 2013, 1-6. [CrossRef]

33. Haijun, Z.; Bingwu, L. A New Genetic Algorithm for Order-Picking of Irregular Warehouse. In Proceedings of the 2009 International Conference on Environmental Science and Information Application Technology, Wuhan, China, 4-5 July 2009; Volume 1, pp. 121-124. [CrossRef]

34. Liu, Y.; Ji, S.; Su, Z.; Guo, D. Multi-objective AGV scheduling in an automatic sorting system of an unmanned (intelligent) warehouse by using two adaptive genetic algorithms and a multi-adaptive genetic algorithm. PLoS ONE 2019, 14, e0226161. [CrossRef] [PubMed] 
35. Mallawaarachchi, V. Introduction to Genetic Algorithms Code. Available online: https:/ / towardsdatascience.com/introductionto-genetic-algorithms-including-example-code-e396e98d8bf3 (accessed on 29 May 2021).

36. Tecnomatix Plant Simulation Help. Available online: https://docs.plm.automation.siemens.com/content/plant_sim_help/ 15/plant_sim_all_in_one_html/en_US/tecnomatix_plant_simulation_help/tecnomatix_plant_simulation/tecnomatix_plant_ simulation_help.html (accessed on 10 March 2021). 